\title{
Annona muricata's Leaves Ethanolic Extract Enhance p53 Expression in Rat Hepatic Cells Induced by Dimethylbenz(a)Anthracene (DMBA)
}

\author{
Rosa Adelina ", Intan Sari Oktoberia, and Putri Reno Intan \\ Biomedical and Basic Health Technology Center, National Institute of Health and Research Development, \\ Ministry of Health, Jalan Percetakan Negara No. 29, Jakarta, Indonesia
}

\begin{abstract}
Annona muricata or soursop contains acetogenin which can induce apoptosis in vitro and has cytotoxic effect. The study has been done to examine soursop leaves extract's potency in vivo especially to induce apoptosis in 7,12-Dimethylbenz[a]anthracene (DMBA)induced Sprague Dawley rats. The induction process was done twice a week for five weeks. The soursop leaves extract were given in three dosages, that are 200,400 , and $800 \mathrm{mg} / \mathrm{kgBW}$ for seventeen days after two weeks DMBA induction. Data analysis showed that Annona muricata leaves ethanolic extract could enhance p53 pathway significantly with a dose independent manner in DMBA-induced rats.
\end{abstract}

Keywords: Proapoptosis, Annona muricata leaves ethanolic extract, hepatoma

\section{INTRODUCTION}

Death caused by cancer showed high incidence and is increasing by the year. Primary liver cancer is the fifth most common cancer worldwide and the third most common cause of cancer mortality (Parkin, 2001). According to WHO, in 2013 the amount of cancer patients increased about seven million cases and $2 / 3$ of them lived in developing countries (American Cancer Society, 2013). If these cases cannot be controlled, there will be 26 million people suffering from cancer and 17 million of them die of cancer in 2030. Ironically, Union for International Cancer Control in 2009 said that this incidence will grow faster in poor and developing countries (Yayasan Kanker Indonesia, 2012).

In United States, more than 12.000 death cases per year were related to liver cancer (Thuluvath, et al., 2006). Based on Basic Health Research (RISKESDAS), cancer prevalence in Indonesia was 1.4 per 1,000 people (NIHRD, 2013). While, liver cancer incidence for men is 11:100,000 and 3:100,000 populations for women and it has become the third common cause of cancer for men (Pfizer, 2013). The incidence level of liver cancer in men was three times higher than in women and during 2005-2009 the incidence number increased to $2.3 \%$ per year in men and $1.3 \%$ in women (American Cancer Society, 2013).

Up to $80 \%$ of 30,640 liver cancer cases occurred in United States was hepatocellular carcinoma (HCC), originating from hepatocytes. Common symptoms include abdominal pain and/or swelling, weight loss, weakness, loss of appetite, jaundice, and fever. Moreover, enlargement of the liver is the most common physical sign. Some of liver cancer risk factor were alcohol-related cirrhosis, possibly nonalcoholic fatty liver disease associated with obesity, chronic infections with hepatitis B virus (HBV) and hepatitis C virus (HCV) (American Cancer Society, 2013).

\footnotetext{
*Corresponding author e-mail: rosa.adelina@litbang.depkes.go.id
} 
Generally, cancer was treated with surgery, chemotherapy, or radiotherapy. However, those treatments showed toxic side effects in normal tissues and also generate resistance in cancer cells (King, 2000; Tyagi, et al., 2004). Therefore, the drug development for a safe, effective, and selective cancer treatment is important to be investigated (Gibbs, 2000). The new drug discovery for cancer based on natural product is potential to be developed (Walaszek, et al., 2004).Previous study showed that natural compounds were able to inhibit and/or kill cancer cell, showing their potential as anticancer agents (Umadevi, et al., 2013). One of the potential plants is soursop leaves (Annona muricata L.). Annona muricata leaves contain acetogenin, essential oil, reticuline, loreximine, coclaurine, annomurine, and higenamine. Acetogenin group was the phytochemical components in Annona muricata leaves possessing potential effect as anticancer.

Annona muricata leaves have seventeen acetogenin compounds showing cytotoxic effect (Kim, et al., 1998). Bullatacin, one of the acetogenin compound,were able to induce apoptosis in hepatoma in vitro (Chih, et al., 2001). Based on several researches above, this study aimed to explore Annona muricata leaves extract potency to induce apoptosis in 7,12dimethylbenz[a]anthracene-induced rats by enhancing p53 expression. Therefore, this study used experimental animal to in vivo anticancer study.

\section{MATERIALS AND METHODS}

\section{Location}

This study was conducted in the Pharmacy and Experimental Animal Laboratories, Biomedical and Basic Health Technology, National Institute of Health Research and Development, Ministry of Health.

\section{Extraction}

Annona muricata leaves were collected from South Tangerang and were determined in Indonesian Institute of Science. Fresh leaves of Annona muricata (6 kg) were dried and ground to a coarse powder $(1.36 \mathrm{~kg})$, followed by maceration with $16 \mathrm{~L} 96 \%$ ethanol (Merck) at room temperature for 3 days, stirred every day for five minutes. The ethanolic extract was filtered and concentrated by rotary evaporator, yielding $105.30 \mathrm{~g}$ concentrated extract.

\section{Animals}

A total of 30 female Sprague Dawley rats (40 days old), weighed 30-60 g were taken from experimental animal laboratory. The animals were kept for at least one week before use and the rats were given standard pellet diet and water ad libitum.

\section{Experimental Procedure}

All animals were divided into five groups, 6 rats in each group, that are negative control (Group 1); DMBA control (Group 2); extract dose 200 (Group 3); 400 (Group 4); 800 $\mathrm{mg} / \mathrm{kgBW}$ (Group 5). Oral treatment of DMBA (Sigma) at dose $20 \mathrm{mg} / \mathrm{kgBW}$ were given twice a week for five weeks. DMBA was dissolved in corn oil and extract was dissolved in $0.5 \%$ CMC-Na. All groups were not treated for two weeks $\left(6^{\text {th }}-7^{\text {th }}\right.$ week) to wait tumor growth. Then, group 3.4, and 5 were administered once a day by 200, 400, and $800 \mathrm{mg} / \mathrm{kgBW}$ extract respectively for 17 days. Body weights were recorded weekly throughout the study. After 66 days experiment, all animals were sacrified by ketamine. At necropsy, liver were collected and fixed in $10 \%$ buffered formalin.

\section{Ethical Clearance}

This study had ethical clearance from ethical committee of National Institute of Health Research and Development.

\section{Protein p53 Immunohistochemistry Staining}

The liver was sliced into 3-5 $\mu \mathrm{m}$ tissue slices and embedded with paraffin. The organ section were washed out with xylene to clear up the paraffin and dehydrated with ethanol (Merck). The slides were immersed in water for one minute. For antigen retrieval, the slides were boiled in citrate buffer $(\mathrm{pH}$ 6.0) for 15 
minutes and subsequently cooled for 20 minutes. The slides were washed in phosphatebuffered saline (PBS) (pH 7.4), and endogenous peroxidase was blocked by $0.3 \%$ hydrogen peroxide for 15 minutes. After that, the sections were incubated at $25^{\circ} \mathrm{C}$ with anti-p53/Clone PAb 240 for 10 minutes.

The slides were washed with PBS and then the section were incubated at $25^{\circ} \mathrm{C}$ with horse radish peroxidase as secondary antibody for 10 minutes. Then, the slides were incubated for 10 minutes at $25^{\circ} \mathrm{C}$ with diaminobenzidine (DAB) and counter stained with haematoxylin eosin before mounting.

\section{Data Analysis}

The data was analyzed quatitatively by cell color observation. The observation was done as 10 fields of view. The positive expression of p53 showed brown color in cell cytoplasm. The negative expression showed by the absence of brown color in cell cytoplasm.

\section{RESULTS AND DISCUSSION}

Apoptosis or programmed cell death is needed for the maintenance of cell homeostasis and to destroy cells that represent a threat to the integrity of organism. Protein p53 is a protein that play important role on apoptosis mechanism. Indeed, its absence has disastrous effects, such as genomic instability, deregulated metabolism of reactive oxygen species, unleashed acute inflammation, cancer, developmental malformations. In cancer treatment, idea of trying to turn p53 "on" is solidly based on the factthat $\mathrm{p} 53$ deficiency is a bad prognostic factorin cancer. Inactivation of p53 some cell types are prone to a predominantly apoptotic response almost regardless of the severity of DNA damage or growth arrest (Gudkov and Kamarova, 2010).

In contrast, casein associates with p53 on the promoters of several proapoptotic genes within chromatin and activates methylation within the transcribed regions of the genes. This increases their transcription and promotes apoptosis (Das, et al., 2007; Tanaka, et al., 2007). p53 is inactivated (directly or indirectly) in the vast majority of human tumors (Soussi, et al., 2000), and loss of p53 in tumors is associated with an unfavorable prognosis in many forms of cancer.

This has led the p53 field to predominantly focus on the possibility of restoring p53 activity as a way to induce cancer cell death (Midgley, et al., 2000; Bykov, et al., 2002; Issaeva, et al., 2004; Vassilev, et al., 2004). In this study we would like to figure out the inhibition of carcinogenesis is by observing the expression of apoptotic protein. Protein p53 is a multifunctional protein regulating cell division and activating apoptosis. In this study, we used anti-p53 staining to observe cytoplasmic color intensity, because the anti-p53 was expressed in cytoplasmic cell, while p53 expression happens in nuclear cell (Looi, et al., 2008; Halasova, et al., 2009).

Immunohistochemistry staining resulted brown-stained in the cytoplasm of liver cells were classified as positive regardless of staining intensity. High intensity of brown area showed high expression of anti-p53. Fig. 1 showed that DMBA control group highly expressed anti-p53 and the expression of anti-p53 decrease gradually in extract-treated groups (group 3-5). Group 5 showed anti-p53 expression like group 1. Therefore, the apoptosis mechanism might occur via p53-dependent pathways. We should explore another mechanism of anticancer of Annona muricata leaves ethanolic extract. This data strengthen in vitro assay revealing Annona muricata leaves ethanolic extract mechanism to inhibit cancer progression by enhancing apoptosis (Chih, et al., 2001). In conclusion, Annona muricata leaves ethanolic extract was potential to be developed as anticancer agent. 


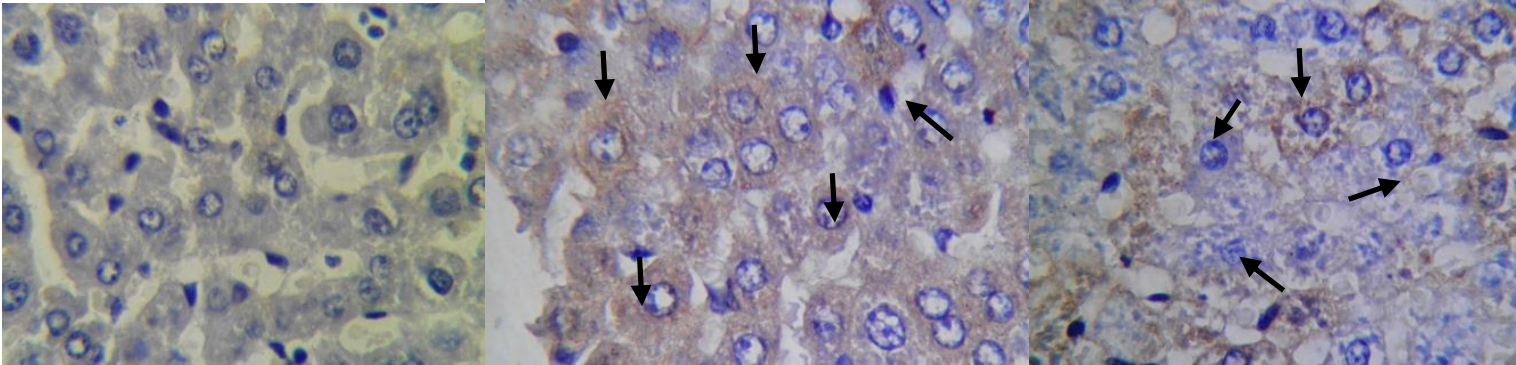

(A)

(B)

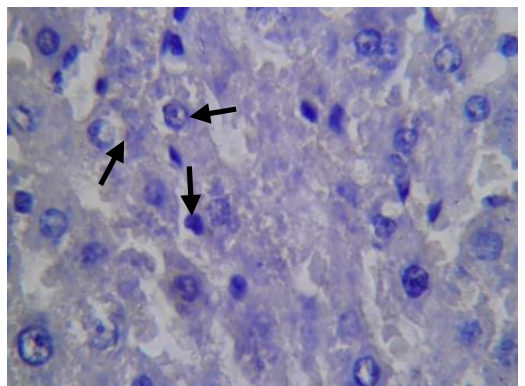

(D)

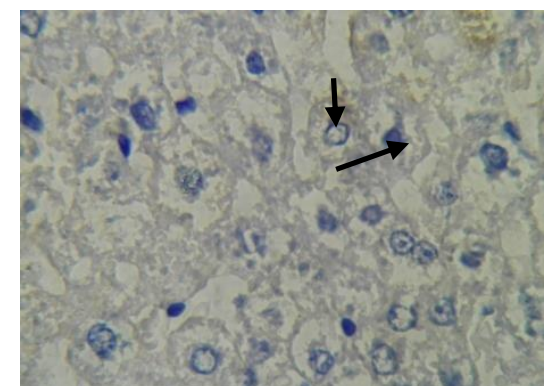

(E)

Figure I. fugAnnona muricata leaves extract decreased anti-p53 expression in liver cells in 7,12dimethylbenz[a]anthracene-induced rats.(A) Negative control group (Group I), (B) DMBA control group (Group 2), (C) Extract dose $200 \mathrm{mg} / \mathrm{kgBW}$ group (Group 3), (D) Extract dose 400 $\mathrm{mg} / \mathrm{kgBW}$ group (Group 4), and (E) Extract dose $800 \mathrm{mg} / \mathrm{kgBW}$ group (Group 5).

\section{ACKNOWLEDGEMENT}

We are grateful to National Institute of Health Research and Development, Ministry of Health, for Health Research Grant (2012) and team support from Pharmaceutical Laboratory and Experimental Animal Laboratory of National Institute of Health Research and Development.

\section{REFERENCES}

American American Cancer Society [editorial], 2013, Cancer Facts and Figures 2013, Website, http://www.cancer.org/ research/cancerfactsfigures/cancerfacts figures/cancer-facts-figures-2013.

Bykov, V.J., Issaeva, N., Shilov, A., Hultcrantz, M., Pugacheva, E., Chumakov, P., et al., 2002, Restoration of the Tumor Suppressor Function to Mutant p53 by a LowMolecular-Weight Compound, Nat. Med., 8(3), 282-288.
Chih, H., Chiu, H.F., Tang, K.S., Chang, F.R. and Wu, Y.C., 200I, Bullatacin, a Potent Antitumour Annonaceous Acetogenin, Inhibits Proliferation of Human Hepatocarcinoma Cell Line 2.2.15 by Apoptosis Induction, Life Sci., 69(II), |32|-|33|.

Das, S., Raj, L., Zhao, B., Kimura,Y., Bernstein, A., Aaronson, S.A., et al., 2007, $\mathrm{Hzf}$ Determines Cell Survival Upon Genotoxic Stress by Modulating p53 Transactivation, Cell., I30(4), 624-637.

Gibbs, J.B., 2000, Anticancer Drug Targets: Growth Factor and Growth Factor Signaling, J. Clin. Invest., I 05(I), 9-I 3.

Gudkov, A.V. and Komarova, E.A., 2010, Pathologies Associated with the p53 Response, Cold Spring Harb. Perspect Biol., 2, a00I I 80.

Halasova, E., Adamkov, M., Kavcova, E., Matakova, T., Musak, L., Vybohova, D., et al, 2009, Expression of Anti-Apoptotic Protein Surveivin and Tumor Supressor p53 Protein in Patients with Pulmonary Carcinoma, Eur. J. Med. Res., I4(4), 97-100. 
Issaeva, N., Bozko, P., Enge, M., Protopopova, M., Verhoef, L.G., Masucci, M., et al., 2004, Small Molecule RITA Binds to p53, blocks p53-HDM-2 Interaction and Activates p53 Function in Tumors, Nat. Med., I 0(I2), I 32 I-I328.

Kim, G., Zeng, L., Alali, F., Rogers, L.L., Wu, F., McLaughlin, J.L., et al., 1998, Two New Mono-Tetrahydrofuran Ring Acetogenins, Annomuricin $\mathrm{E}$ and Muricapentocin, from the Leaves of Annona muricata, J. Nat. Prod., 6 I(4), 432-436.

King, R.J.B., 2000, Cancer Biology, 2nd Edition., London: Pearson Eduation Limited.

Looi, M.L., Dali, A.Z.H.M., Ali, S.A.M., Ngah, W.Z.W. and Yusof, Y.A.M., 2008, Expression of p53, BCl-2, and $\mathrm{Ki}-67$ in Cervical Intraepithelial Neoplasia and Invasive Squamous Cell Carcinoma of the Uterine Cervix, 30(2), Website, http://www.aqch.com/feature/2008/feat ure042008.php.

Midgley, C.A., Desterro, J.M., Saville, M.K., Howard, S., Sparks, A., Hay, R.T., et al, 2000, An N-terminal pl4ARF Peptide Blocks Mdm2-Dependent Ubiquitination In Vitro and Can Activate p53 In Vivo, Oncogene., I 9(19), $2312-2323$.

National Institute of Health Research and Development (NIHRD), 2013, Penyajian Pokok-Pokok Hasil Riset Kesehatan Dasar 2013, Jakarta: Ministry of Heath.

Parkin, D.M.,200I, Global Cancer Statistics in The Year 2000, Lancet Oncol., 2(9), 533543.

Pfizer, 2013, Pfizer Fact: The Burden of Cancer in Asia, http://www.pfizer.com/files/products/ca ncer_in_asia.pdf.

Soussi, T., Dehouche, K. and Beroud, C., 2000, p53 Website and Analysis of p53 Gene Mutations in Human Cancer: Forging a Link Between Epidemiology and Carcinogenesis, Hum. Mutat., I 5(I), I05-II3.

Tanaka, T., Ohkubo, S., Tatsuno, I. and Prives, C., 2007, hCAS/CSEIL Associates with Chromatin and Regulates Expression of Select p53 Target Genes, Cell, I 30(4), 638-650.

Thuluvath, P.J., Choti, M., Geschwind, J.F., Norwitz, L. and Kalloo, A.N., 2006, Liver Cancer, Website, https://gastro.nts.jhu.edu.

Tyagi, A.K., Agarwal, C., Chan, D.C.F. and Agarwal, R., 2004, Synergistic Anticancer Effects of Silibini with Conventional Cytotoxic Agents Doxorubicin, Cisplatin and Carboplatin Against Human Breast Carscinoma MCF-7 and MDA-MB468 Cells, Oncol. Rep., I I (2), 493-499.

Umadevi, M., Kumar, K.P.S., Bhowmik D, and Duraivel S, 2013, Traditionally Used Anticancer Herbs in India, J. Med. Plants. Stud., I (3), 56-74.

Vassilev, L.T., 2005, p53 Activation by Small Molecules: Application in Oncology, J. Med. Chem., 48(I4), 449 I-4499.

Walaszek, Z., Hanausek, M. and Slaga, T.J., 2004, Mechanisms of Chemoprevention, Supplement American College of Physicians, I 25(5), I28-I 33.

Yayasan Kanker Indonesia, 20I2, YKI-Jakarta Race, Website, https://yayasankankerindonesia.org/20I 2/yki-jakarta-race/. 